\title{
Traditional Market Problems in Semarang City
}

\author{
Yearzy Ferdian ${ }^{1}$, Sri Suwitri ${ }^{2}$, Hardi Warsono ${ }^{3}$, Hartuti Purnaweni ${ }^{4}$ \\ \{sri_suwitri@yahoo.co.id ${ }^{2}$ \} \\ Universitas Diponegoro, Indonesia ${ }^{1,2,3,4}$
}

\begin{abstract}
The development of the current era has an impact on declining community desire to stroll in traditional markets. This is evident from the increasingly traditional market in Semarang City; there even some markets that are experiencing closure. There is a revitalization effort done by the Government of Semarang City also does not seem to bring significant results to improve performance in the traditional market of Semarang City. The objective of this research is Bulu traditional market. This research describes the problem that experienced by traditional market in Semarang City. The method of research done is with qualitative descriptive analysis. The results showed the traditional market problem in Semarang City is a decline in turnover caused by the decline in the number of consumers who shop in traditional markets. The rapidly growing modern retail developments make the role and market share of the traditional market increasingly terriers. The character of the community in Semarang City who wants the practicality to make purchases and modern society that wants cleanliness, so it tends the desire to stroll in a market that is horizontal form also make revitalizing program is not Goes well. Traders feel that the buyer feels lazy to climb upstairs while the trader their selves also feels that the multilevel market also complicate traders to include merchandise because there is no access to the vehicle and the trader should bring the whole through stairs. This condition indicates that the new building in the traditional market does not meet the needs of business traders. Traders in the traditional market also complained about the high cost of rent so that traders feel that selling in the traditional market is now less profitable when compared to entrust trades in the modern market.
\end{abstract}

Keywords: Traditional Market, Semarang City, Trader.

\section{Introduction}

The economic development of the city is determined by the flow of the trading system in the city itself. One of the trading tools that until now remain in the rural and urban environment is a traditional market. The typical nature of the traditional market has an important function whose existence can never be replaced by the modern market. The traditional market has economic function is a place where people from various layers acquire daily necessities with a relatively affordable price because it is often relatively cheaper than the price offered by the modern market. In other words, the traditional market is a pillar of small community economic buffer. The traditional market is also a place that is relatively more accessible by weak economic actors who occupy a majority position, especially those with small capital. In addition, the traditional market is one source of Local Own-source Revenue, through retribution withdrawn from traders. The accumulation of trading activities in the market is an important factor in the calculation of economic growth in local, regional and national scale. 
The phenomenon of Asian economic developments lately is one of the growing factors of retail business, especially modern retail business that has begun to shift the role of traditional markets as a pillar for the country's economy. This can happen due to the increasing number of local and foreign companies investing in the modern retail sector. The modern market that penetrated Indonesian society today has an impact on the existence of traditional markets.

The growth of modern stores in Semarang City is now the first time so fast and increasing. Many modern minimarket or stores suspected because the increasing population factor, along with the high population growth, automatically the needs of the Daily society also increased. This is due to the emergence of modern markets that are in value potential by retail businesspersons. Modern retail growth is quite rapidly nowadays is a minimarket with franchise concept or franchise [1].

\section{Methodology}

Research on the problems that occur in the traditional market in Semarang City is using qualitative descriptive research methods. The informants of this research are the trader in Bulu traditional market. They are classified bases on their experience in trading activity. The selection of this qualitative approach based on several considerations. First, the value of truth is credibility, namely the conformity between concepts of researchers with the concept of respondents. Second, the application is transferability i.e. the results of qualitative research used or applied to other cases or situations. The location of this research is in the traditional market in Semarang City, namely Bulu Market, Sampangan Market and Rejomulyo Baru Semarang Market.

\section{Result and Discussion}

The Conditions that exist in the community where the growth of modern stores that currently dominated by many companies are obviously able to cause impact to local entrepreneurs in the area. Where directly affected by the growth of the outlets or modern stores both Indomaret and Alfamart are the grocery store entrepreneurs around the neighbourhood Alfamart and Indomaret outlets. In addition, people often look at the market as a place that is less clean, ancient and unhygienic so that many people make the community, especially the younger generation prefers to shop in modern stores.

With the development of modern stores that are widely established by investors, the existence of traditional stalls and a stand-alone and economically based grocery store will have a decline. This is due to the emergence of modern markets that are in value potential by retail businessmen. Modern retail growth is quite rapidly nowadays is a minimarket with franchise concept or franchise [1]. It is contrasted if comparing between traditional market growths with modern market.

Table 1. Total Locations of Traditional Markets in Semarang City

\begin{tabular}{lccc}
\hline Sub-Districts & 2015 & 2016 & 2017 \\
\hline Mijen & 1 & 1 & 1 \\
Gunungpati & 1 & 1 & 1 \\
\hline
\end{tabular}




\begin{tabular}{lccc}
\hline Sub-Districts & 2015 & 2016 & 2017 \\
\hline Banyumanik & 5 & 5 & 5 \\
GajahMungkur & 1 & 1 & 1 \\
Semarang Selatan & 5 & 5 & 5 \\
Candisari & 3 & 3 & 3 \\
Tembalang & 2 & 2 & 2 \\
Pedurungan & 6 & 6 & 6 \\
Genuk & 3 & 3 & 3 \\
Gayamsari & 2 & 2 & 2 \\
Semarang Timur & 4 & 4 & 4 \\
Semarang Utara & 4 & 4 & 4 \\
Semarang Tengah & 10 & 10 & 9 \\
Semarang Barat & 3 & 3 & 3 \\
Tugu & 1 & 0 & 0 \\
Ngaliyan & 4 & 4 & 4 \\
\hline Total & 54 & 53 & 52 \\
\hline Source: Semarang City & Trade Office & BPPT, & $2018)$
\end{tabular}

Source: Semarang City Trade Office (BPPT, 2018).

According to the table above, it is seen that the traditional market is actually experiencing a decline in terms of number, while the traditional market spread itself is uneven, as does the modern store. Even the number of traditional markets that decline is precisely the place replaced by modern stores that take the market from the traditional market; this makes the traditional market increasingly marginalized in the community. This condition is a separate phenomenon that is linear with the realization of regional indigenous revenue; the traditional market is able to donate retribution that is always declining annually.

Table 2. Retribution of Traditional Market in Semarang City

\begin{tabular}{cccc}
\hline Years & Retributions (IDR) & Targets & Achievements \\
\hline 2014 & 18.631 .633 .416 & 20.451 .750 .000 & $-8.90 \%$ \\
2015 & 14.333 .315 .721 & 15.529 .750 .000 & $-7.70 \%$ \\
2016 & 13.077 .835 .179 & 14.858 .945 .000 & $-11.99 \%$ \\
\hline 2017 (September) & 10.941 .205 .218 & 17.318 .945 .000 & $-36.83 \%$ \\
\hline
\end{tabular}

Based on the data in the table above, it is known that from the income of retribution which is a role of regional genuine revenue, traditional market levy never reach a target defined annually, even every year is always experiencing a decline. Most traditional markets in Indonesia is managed by the local government through the relevant agencies and in the form of Regional Companies (PD). As a traditional market maintainer, governments should be proactive against the rise of modern markets and traditional market positions that require special attention.

The existence of these rules at least signals that government policies have been on the sides and protect the existence of traditional markets. In this regulation, there is an obligation to conduct a review of the impact for socio-economic (and the economy of the city: traditional market, SMEs) as a consideration material before setting up the market (new), shopping center, or store Modern [2].

The main problem of the traditional market in Semarang City as an example is Bulu market that is the markets on the second and third floor of the day seems lonely and traders complain of a decline in turnover. This can happen because there is no access to the buyer to go straight to the top floor, the character of the market buyer who wants the practicality to make a purchase, to want to shop in a market that is horizontally shaped and not Vertical. This 
condition also affects that Bulu market traders who choose to sell outside this area in Barusari which raises new problems in Semarang City, which is congestion on the road, because the trader held the trade to meet the section Road so that the road is difficult to pass by the motor during working hours. It also considered because the management of traditional market management is less professional, so it needs a breakthrough to keep traditional markets able to suck people to do economic activity in traditional markets.

The same problem also experienced due to revitalizing Sampangan market. Traders complain about the high rental fee so that traders feel that selling at Sampangan market is no longer profitable. The Buyers also feel that the price of groceries in Sampangan market is higher than other places also looking for another alternative that is a little further so that Sampangan market is quiet from the buyer. This condition turns off some Sampangan market especially the upper floor, which only occupied three traders from dozens of existing los. This is because traders feel that the buyer feels lazy to climb upstairs while the trader theirshelve also feels that the multilevel market also complicate traders to include merchandise because there is no access to vehicles and traders should carry the entire trade through the stairs.

The condition experienced by Pasar Rejomulyo is slightly different from Bulu market and Sampangan market. The revitalization carried out by the Semarang City Government by moving traders in Kobong Market to Pasar Baru Rejomulyo was a protest and lawsuit from the group of merchants Market Kobong to Semarang City Government. This lawsuit carried out because the trader felt not involved in the revitalization plan and asked to move to a new building in a short time. The problem is that the new building is not eligible for fish trading at the largest Rejomulyo Baru Semarang Market in Java. These inappropriate conditions include ceramic floors that are harmful to both traders and buyers because they are slippery, drains are too small so that potentially clogged, unloading land that is too high and can only be used by a single truck in a single chunk period. This condition makes Rejomulyo Baru Semarang Market only charged less than $10 \%$ of its capacity because most traders choose to keep selling in Kobong market; this shows the failure of revitalization done by Semarang City Government.

The revitalization of the area is an attempt to revive the dead region, which in the past lived, or controlled and developed the region to rediscover the potential owned or ever owned or that should have been owned by a city. That is expected to provide an increase in the city's environmental quality, which ultimately affects the quality of life of its inhabitants [3]. The revitalization done should also not always related to the physical development of traditional market buildings but the most important stage in the revitalization of traditional markets is to improve the behavior of traders in providing services to consumers. [4], who researched entitled Revitalization of the Gil-Dong Traditional Market in Korea, showed the results that traditional market revitalization aimed at attracting younger generation consumers.

Physical intervention initiates physical activity of revitalization and is carried out gradually, covering the improvement and improvement of the quality and physical condition of the building, green layout, connective system, signs/billboards and open space areas [5].

\section{Conclusion}

The problem that currently experienced by the traditional market in Semarang City is the traditional market today considered less attractive as a place to shop for millennials who have a practical lifestyle. The problem in the traditional market itself is the arrangement of Semarang City Government of is currently not able to fulfill the needs for consumers and 
business people themselves. Education in the community to make the traditional market as the main choice in shopping is also done, such as involving schoolchildren to race to draw with the theme of traditional markets, or exhibitions of photographs and other activities Introducing traditional market privileges. The activities are organized regularly and periodically by involving schoolchildren and various other community components. This traditional market revitalization is indeed the responsibility of all parties or all components of the community.

As a suggestion of the gap in the results of traditional market, revitalization done in Semarang City as mentioned above this shows that there needs to be a revitalizing model of traditional market in Semarang City. That can be padding all over Market stakeholders such as traders 'interests, as well as following the economic, social and cultural transformation of society.

\section{References}

[1] W. R. Jati, "Bonus Demografi Sebagai Mesin Pertumbuhan Ekonomi: Jendela Peluang Atau Jendela Bencana Di Indonesia?,” Populasi, 2015, doi: 10.22146/jp.8559.

[2] Kementrian Dalam Negeri, Peraturan Menteri Perdagangan Republik Indonesia Nomor 37/MDAG/PER/5/2017. 2017

[3] J. C. Jenkins, "Resource Mobilization Theory and the Study of Social Movements," Annu. Rev. Sociol., 1983, doi: 10.1146/annurev.so.09.080183.002523.

[4] J. Kim, "Revitalization of the Gil-Dong Traditional Market in Korea," J. Mark. Thought, 2014, doi: 10.15577/jmt.2014.01.02.58.

[5] J. Beall and S. Fox, "Urban poverty and development in the 21 st century: towards an inclusive and sustainable world," Development, 2007. 